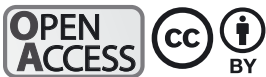

\section{Low susceptibility of sockeye salmon Oncorhynchus nerka to viral hemorrhagic septicemia virus genotype IVa}

\author{
Lynden Gross ${ }^{1}$, Jon Richard ${ }^{1}$, Paul Hershberger ${ }^{2}$, Kyle Garver ${ }^{1, *}$ \\ ${ }^{1}$ Fisheries and Oceans Canada, Pacific Biological Station, Nanaimo, BC V9T 6N7, Canada \\ ${ }^{2}$ US Geological Survey, Western Fisheries Research Center, Marrowstone Marine Field Station, Nordland, WA 98358, USA
}

\begin{abstract}
Viral hemorrhagic septicemia virus (VHSV) genotype IVa is an endemic pathogen to the marine waters of British Columbia, with numerous marine fishes being susceptible to infection and disease, including Atlantic salmon Salmo salar reared in open net-pen aquaculture. The susceptibility of Atlantic salmon and sockeye salmon Oncorhynchus nerka to VHSV-IVa infection was evaluated using exposure routes including injection, static immersion, and cohabitation with diseased Pacific herring Clupea pallasii. Exposed fish were monitored for mortality and external pathology, mortalities were tested by virus isolation assay, and live fish were regularly sampled and screened for infection. Among injected sockeye, VHSV was detected in 1 mortality $(\mathrm{n}=195)$ and 2 sub-sampled fish $(\mathrm{n}=30)$, whereas sockeye exposed by immersion and cohabitation did not experience mortality nor was systemic infection indicated by tissue screening. Injection and cohabitation exposure routes confirmed the susceptibility of Atlantic salmon to VHSV. Neither sockeye nor Atlantic salmon surviving the cohabitation served as a reservoir of VHSV, but Pacific herring did. The results suggest that VHSV-IVa poses low risk to sockeye salmon under natural routes of exposure.
\end{abstract}

KEY WORDS: Viral hemorrhagic septicemia virus $\cdot$ VHSV $\cdot$ Sockeye salmon $\cdot$ Susceptibility

\section{INTRODUCTION}

Sockeye salmon Oncorhynchus nerka is a keystone species in the North Pacific Ocean that is highly prized as a food commodity. Of the 7 species of Pacific salmon, sockeye salmon are the third most abundant after pink salmon $O$. gorbuscha and chum salmon $O$. keta. Due to their preferential use of lake habitats in juvenile rearing stages, the distribution of sockeye salmon is largely restricted to north temperate rivers with accessible lakes.

The Fraser River drainage of British Columbia, possessing extensive lake rearing areas, supports one of the largest spawning complexes of sockeye salmon in the North Pacific Rim (Burgner 1991). However,

*Corresponding author: kyle.garver@dfo-mpo.gc.ca between the early 1990s and 2009, fisheries managers and biologists recognized a steady and profound decline in Fraser River sockeye productivity. In 2009, record low returns of sockeye salmon to the Fraser River forced closure of the fishery for the third consecutive year and prompted a federal investigation, the Commission of Inquiry into the Decline of Sockeye Salmon in the Fraser River. After review of numerous technical reports and testimonies of expert witnesses, the Commission concluded that sockeye salmon experience multiple stressors that may affect their health and their habitats at various stages of their life and suggested that multiple factors likely contributed to the decline (Cohen 2012). Moreover, the Commission highlighted knowledge gaps, uncer(C) Fisheries and Oceans Canada, and outside the USA, the US Government 2019. Open Access under Creative Commons by Attribution Licence. Use, distribution and reproduction are unrestricted. Authors and original publication must be credited. 
tainties, and future research needs to provide better information about the challenges faced by Fraser River sockeye.

In particular, one uncertainty identified by the Commission was whether diseases and pathogens from open net-pen salmon farms in British Columbia contributed to the population decline or may pose risks of significant harm to Fraser River sockeye. In the marine environment of British Columbia, there are 109 licensed salmon farm sites with approximately 60 to 70 farms actively operating at a given time. As netpen farms reside in the oceanic environment, there exists a potential risk of pathogen exchange between farmed and wild fish. To evaluate the risks and potential impacts of such pathogen transmission events, it is imperative to understand endemic disease effects in both wild and farmed fish species.

Viral hemorrhagic septicemia virus (VHSV) genotype IVa is one endemic pathogen in the marine waters of British Columbia that has spilled over and caused disease in farmed Atlantic salmon Salmo salar (Garver et al. 2013). VHSV is common in the Northeastern Pacific Ocean where it has caused disease in numerous marine species, including Pacific herring Clupea pallasii, Pacific hake Merluccius productus, walleye pollock Theragra chalcogramma, and Pacific sardines Sardinops sagax (Meyers et al. 1999, Traxler et al. 1999). Laboratory studies conducted on the highly abundant marine species Pacific herring confirmed their extreme susceptibility to viral hemorrhagic septicemia (VHS) disease and demonstrated their capacity to serve as a natural reservoir of VHSV (Kocan et al. 2001, Hershberger et al. 2010). Furthermore, molecular epidemiological investigations suggest that wild Pacific herring and sardines are a source of virus to farmed Atlantic salmon in British Columbia, where VHSV is detected nearly annually (Garver et al. 2013). However, the complete disease ecology of VHSV in the Northeastern Pacific Ocean is uncertain, and the host range of VHSV-IVa undoubtedly extends beyond the aforementioned species. Field surveillance programs have isolated the virus from a number of other marine species, including Pacific salmon species (Amos et al. 1998, Hedrick et al. 2003). The World Organisation for Animal Health (OIE) listed Chinook $O$. tshawytscha, coho O. kisutch, and Atlantic salmon as fish species for which there is conclusive evidence of susceptibility to VHSV infection, while sockeye salmon are listed as a species for which there is incomplete data to determine susceptibility (Marty et al. 2006, EFSA 2008, OIE 2019). Laboratory studies exposing freshwater coho, Chinook, pink and sockeye salmon suggest a refractory nature to VHSV (Follett et al. 1997). Yet, given the marine origin of VHSV, it is of interest to evaluate the susceptibility of salmonids to infection at a marine life stage.

To this end, our study investigated the susceptibility of saltwater-phase sockeye salmon to VHSV genotype IVa infection through injection, immersion, and cohabitation exposures.

\section{MATERIALS AND METHODS}

\subsection{Virus inoculum}

Equal concentrations of 4 VHSV genotype IVa isolates were mixed to produce a virus inoculum for each experimental infection. The VHS viruses were isolated from salmonid and non-salmonid species and are representative of the VHSV variants endemic to the marine waters of British Columbia (Table 1) (Garver et al. 2013). The isolates were amplified using the epithelioma papulosum cyprini (EPC) cell line, titered via plaque assay on EPC cell culture (Batts et al. 1991), and diluted in Hanks' Balanced Salt Solution with $1 \times$ Antibiotic-Antimycotic (HBSS+Ab, pH 7.2 to 7.8; GIBCO) to reach the specified exposure levels. At the time of challenge, the virus inoculum was titered to verify that each virus challenge experiment was conducted at the desired exposure level.

\subsection{Fish}

Experimental animals consisted of fish with unknown susceptibility (sockeye salmon Oncorhynchus nerka), low to moderate susceptibility (Atlantic salmon Salmo salar) and high susceptibility (Pacific herring Clupea pallasii) to VHSV. Sockeye salmon fry (Pitt River stock) obtained from a freshwater hatchery

Table 1. Viral hemorrhagic septicemia virus (VHSV) genotype IVa isolates used in injection, immersion, and cohabitation studies

\begin{tabular}{|llll|}
\hline Isolate name & Host species & Collection & Location \\
\hline BC 99-001 & Pacific sardine & Jan 1999 & Beaver Cove, Vancouver Island \\
BC 99-292 & Atlantic salmon & Apr 1999 & Southern Vancouver Island \\
BC 283-1B & Chinook salmon & Feb 2005 & West coast of Vancouver Island \\
BC 06-089-1 & Pacific sardine & Jan 2006 & Rennell Sound, Haida Gwaii \\
\hline
\end{tabular}


were transported to the Pacific Biological Station (PBS, Nanaimo, BC) where they were held in $6^{\circ} \mathrm{C}$ $\left( \pm 1^{\circ} \mathrm{C}\right)$ dechlorinated freshwater under a natural photoperiod. The sockeye remained in fresh water for a minimum of 10 mo and reached average weights of 52 to $80 \mathrm{~g}$ prior to saltwater transition and VHSV exposure. Atlantic salmon smolts (Mowi strain) were obtained from a freshwater hatchery and reared at PBS in $10^{\circ} \mathrm{C}\left( \pm 1^{\circ} \mathrm{C}\right)$ brackish water (salinity 6.5$)$ to average weights of 35 to $59 \mathrm{~g}$ prior to VHSV exposure. At the time of exposure, the salmon were transitioned to $10^{\circ} \mathrm{C}\left( \pm 1^{\circ} \mathrm{C}\right)$ saltwater (salinity 28 to 30$)$. Specific pathogen-free (SPF) Pacific herring juveniles (average weight: $13 \mathrm{~g}$ ) reared at the USGSMarrowstone Marine Field Station (Nordland, WA) were transported to PBS and held in $9.5^{\circ} \mathrm{C}\left( \pm 0.5^{\circ} \mathrm{C}\right)$ saltwater. All fish were fed dry pellets (EWOS) at $1 \%$ of their body weight $\mathrm{d}^{-1}$.

\subsection{VHSV injection, immersion, and cohabitation exposure of sockeye salmon}

The relative susceptibilities of these species to VHSV infection were evaluated by intraperitoneal (IP) injection, immersion, and cohabitation.

For the IP injection $(100 \mu \mathrm{l}$ doses containing $3.9 \times$ $10^{3}$ plaque-forming units [PFU] VHSV), VHSV was administered to groups of sockeye salmon (75 fish triplicate $\operatorname{tank}^{-1}$ ) and Atlantic salmon (72 fish duplicate $\operatorname{tank}^{-1}$ ). Negative controls for each species consisted of single groups of 75 salmon that were injected with $100 \mu \mathrm{l}$ of $\mathrm{HBSS}+\mathrm{Ab}$ in lieu of virus. All treatments were maintained in $450 \mathrm{l}$ tanks supplied with single-pass, UV-treated seawater at $10^{\circ} \mathrm{C}\left( \pm 1^{\circ} \mathrm{C}\right)$. Mortality was monitored daily for up to $21 \mathrm{~d}$ post VHSV exposure. Mortalities were collected and immediately stored at $-80^{\circ} \mathrm{C}$ until necropsy and tissue testing for VHSV. Sub-samples of sockeye salmon (10 fish $\mathrm{d}^{-1}$ ) were sampled from one of the triplicate tanks at 7,14, and $20 \mathrm{~d}$ post VHSV exposure by euthanization in an overdose of buffered TMS; gill, brain, and anterior kidney tissues were collected. The tissue samples were individually flash-frozen in liquid nitrogen and stored at $-80^{\circ} \mathrm{C}$ until RT-qPCR screening for VHSV (Table 2).

Relative susceptibilities to VHSV were further evaluated by waterborne VHSV exposure to groups of sockeye (75 fish triplicate $\operatorname{tank}^{-1}$ ) and Atlantic salmon ( 75 fish duplicate $\operatorname{tank}^{-1}$ ). Fish were immersed in an aerated 1501 static bath containing $6.7 \times 10^{3}$ $\mathrm{PFU} \mathrm{ml} \mathrm{m}^{-1}$ for $1 \mathrm{~h}$, after which water flow was resumed and tanks were filled to $450 \mathrm{l}$. Negative controls con- sisted of 1 tank per species, each containing 75 fish that were immersed in $\mathrm{HBSS}+\mathrm{Ab}$ in lieu of virus. Immediately after addition of VHSV to the tanks, water was sampled to verify the exposure titer. The undiluted water samples, along with 2 serial 10 -fold dilutions in $\mathrm{HBSS}+\mathrm{Ab}$, were each plated as $100 \mu \mathrm{l}$ inoculums on EPC cell culture and monitored for $5 \mathrm{~d}$ to determine virus titer. Sub-samples of sockeye salmon (10 fish $\mathrm{d}^{-1}$ ) were sampled from one of the triplicate tanks at 7,14 , and $20 \mathrm{~d}$ post exposure by euthanization in an overdose of buffered TMS; gill, brain, and anterior kidney tissues were collected. The tissue samples were individually flash-frozen in liquid nitrogen and stored at $-80^{\circ} \mathrm{C}$ until RT-qPCR screening for VHSV (Table 2).

Relative susceptibilities of sockeye salmon to VHSV were further evaluated by cohabitation with diseased herring, a highly susceptible host that is capable of shedding substantial quantities of virus (Hershberger et al. 2010). A laboratory-induced VHSV epizootic was initiated, by distributing SPF Pacific herring into each of ten 4501 tanks (63 fish tank ${ }^{-1}$ ) supplied with single-pass, UV-treated, $10^{\circ} \mathrm{C}\left( \pm 1^{\circ} \mathrm{C}\right)$ seawater. After a $24 \mathrm{~h}$ acclimation period, the water flow was stopped, volume was reduced to 100 l, and VHSV inoculum was added to 8 treatment tanks at a concentration of $7.8 \times 10^{2} \mathrm{PFU} \mathrm{m} \mathrm{m}^{-1}$. Herring in the remaining 2 tanks served as negative controls and were exposed to $\mathrm{HBSS}+\mathrm{Ab}$ in lieu of virus. After $1 \mathrm{~h}$, water flow was restored, and tanks were re-filled. Water samples (5 ml) were taken from each tank immediately after inoculation $\left(T_{0}\right)$ and after the $1 \mathrm{~h}$ exposure period $\left(T_{1 \mathrm{~h}}\right)$ to verify the waterborne exposure level. The undiluted water samples, along with $1 / 2$ and 1/10 dilutions in Minimal Essential Medium with HEPES, GlutaMAX, Antibiotic-Antimycotic, Gentamycin, and $20 \%$ Fetal Bovine Serum (MEM-20+HEPES+Ab, $\mathrm{pH} 7.6$ to 7.8 ; GIBCO), were each plated as $100 \mu \mathrm{l}$ inoculums on EPC cell culture and monitored for up to $14 \mathrm{~d}$ to determine virus titer. The following day, 100 sockeye salmon were added to each of 5 tanks (4 VHSV treatment tanks and 1 negative control tank), and 100 Atlantic salmon were added to each of the remaining 5 tanks. Fish were monitored daily until the experiment was terminated $41 \mathrm{~d}$ post exposure; mortalities were collected and stored at $-80^{\circ} \mathrm{C}$ until necropsy and tissue testing for VHSV. The amount of shed VHSV was assessed by collecting 11 water samples from duplicate tanks in each of the herring + sockeye and herring + Atlantic salmon cohabitant groups at 3,6,8,10,13,15, 17, 21, 23 and $28 \mathrm{~d}$ post exposure. Viral load in the water samples was determined as described for the $T_{0}$ and $T_{1 \mathrm{~h}}$ sam- 
Table 2. Distribution of sockeye salmon Oncorhynchus nerka (ss), Atlantic salmon Salmo salar (As), and Pacific herring Clupea pallasii (Ph) in VHSV susceptibility studies, including the sampling scheme and duration of each study. For the reservoir potential study, survivors refers to VHSV-exposed fish from the first cohabitation, while sentinels refers to unexposed fish cohabited with the survivors. The + symbol between species indicates a cohabitation; na: not applicable

\begin{tabular}{|c|c|c|c|c|c|c|c|c|}
\hline \multirow{2}{*}{$\begin{array}{l}\text { VHSV } \\
\text { susceptibility } \\
\text { study }\end{array}$} & \multicolumn{3}{|c|}{ Total fish in all replicate tanks } & \multirow{2}{*}{$\begin{array}{l}\text { Replicate } \\
\text { tanks } \\
\text { (n) }\end{array}$} & \multicolumn{2}{|c|}{ RT-qPCR } & \multirow{2}{*}{$\begin{array}{l}\text { Negative } \\
\text { control }\end{array}$} & \multirow{2}{*}{$\begin{array}{c}\text { Duration } \\
\text { (d) }\end{array}$} \\
\hline & $\begin{array}{l}\text { Sockeye } \\
\text { salmon }\end{array}$ & $\begin{array}{l}\text { Atlantic } \\
\text { salmon }\end{array}$ & $\begin{array}{c}\text { Pacific } \\
\text { herring }\end{array}$ & & $\begin{array}{l}\text { Sampling } \\
\text { events (n) }\end{array}$ & $\begin{array}{l}\text { Fish } \\
\text { event }^{-1}\end{array}$ & & \\
\hline Injection & 225 & 144 & na & $\begin{array}{l}3 \mathrm{ss} \\
2 \mathrm{As}\end{array}$ & 3 & $10 \mathrm{ss}$ & $\begin{array}{l}75 \mathrm{ss} \\
75 \mathrm{As}\end{array}$ & $\begin{array}{l}20(\mathrm{ss}) \\
21(\mathrm{As})\end{array}$ \\
\hline Immersion & 225 & 150 & na & $\begin{array}{l}3 \mathrm{ss} \\
2 \mathrm{As}\end{array}$ & 3 & $10 \mathrm{ss}$ & $\begin{array}{l}75 \mathrm{ss} \\
75 \mathrm{As}\end{array}$ & 20 \\
\hline $\begin{array}{l}\text { First } \\
\text { cohabitation }\end{array}$ & 401 & 405 & 502 & $\begin{array}{l}4 \mathrm{Ph}+\mathrm{ss} \\
4 \mathrm{Ph}+\mathrm{As}\end{array}$ & $\begin{array}{l}5 \\
5\end{array}$ & $\begin{array}{l}10 \mathrm{ss} \\
10 \mathrm{As}\end{array}$ & $\begin{array}{l}64 \mathrm{Ph}+101 \mathrm{ss} \\
64 \mathrm{Ph}+102 \mathrm{As}\end{array}$ & $\begin{array}{ll}\text { s } & 41 \\
\text { s } & \end{array}$ \\
\hline $\begin{array}{l}\text { Reservoir } \\
\text { potential } \\
\text { cohabitations }\end{array}$ & $\begin{array}{c}196 \text { survivors } \\
\text { na } \\
130 \text { survivors } \\
129 \text { sentinels } \\
\text { na }\end{array}$ & $\begin{array}{c}\text { na } \\
193 \text { survivors } \\
129 \text { sentinels } \\
128 \text { survivors } \\
\text { na }\end{array}$ & $\begin{array}{c}184 \text { sentinels } \\
185 \text { sentinels } \\
\text { na } \\
\text { na } \\
66 \text { survivors } \\
71 \text { sentinels }\end{array}$ & $\begin{array}{c}3 \mathrm{ss}+\mathrm{Ph} \\
3 \mathrm{As}+\mathrm{Ph} \\
2 \mathrm{ss}+\mathrm{As} \\
2 \mathrm{As}+\mathrm{ss} \\
1 \mathrm{Ph}+\mathrm{Ph}^{\mathrm{b}}\end{array}$ & $\begin{array}{c}1 \\
1 \\
1 \\
1 \\
\text { na }\end{array}$ & $\begin{array}{c}15 \mathrm{ss} \\
15 \mathrm{As} \\
10 \mathrm{ss}, 10 \mathrm{As} \\
10 \mathrm{ss}, 10 \mathrm{As}\end{array}$ & $\begin{array}{c}76 \mathrm{ss}+48 \mathrm{Ph}^{\mathrm{a}} \\
69 \mathrm{As}+28 \mathrm{Ph}^{\mathrm{a}} \\
\text { na } \\
\text { na } \\
\text { na }\end{array}$ & $\begin{array}{l}39 \\
40 \\
40 \\
40 \\
42\end{array}$ \\
\hline
\end{tabular}

ples. Additionally, 5 fish were sampled from duplicate tanks in each of the herring + sockeye and herring + Atlantic salmon treatments at 6,10,15,21, and $28 \mathrm{~d}$ post exposure. In parallel, water and fish were sampled from each of the negative control groups. Sub-sampled fish were euthanized in an overdose of buffered TMS and dissected for gill and anterior kidney tissues. The tissue samples were individually flash-frozen in liquid nitrogen and stored at $-80^{\circ} \mathrm{C}$ until RT-qPCR screening for VHSV (Table 2). To confirm VHSV infection among herring mortalities, the anterior kidney was analysed via virus isolation assay on EPC cell culture.

The potential for sockeye salmon, Atlantic salmon and Pacific herring to be a reservoir of VHSV was evaluated by comingling survivors from the first cohabitation exposure with naïve sentinels. Surviving fish from the negative control cohabitations were transferred to new tanks in the same arrangement (Table 2). All recipient tanks were disinfected with Ovadine (Syndel) prior to redistribution to prevent contamination. To distinguish the VHSV-surviving herring from sentinel herring, the surviving herring were clipped at the caudal and left pelvic fins. To evaluate VHSV infection status, 5 sentinel and/or 5 VHSV-surviving salmon were sub-sampled from each of the salmon-containing tanks at 19 or $20 \mathrm{~d}$ into cohabitation; gill and anterior kidney tissues were collected. The tissue samples were individually flashfrozen in liquid nitrogen and stored at $-80^{\circ} \mathrm{C}$ until RT-qPCR screening for VHSV. Additionally, water samples were collected from the VHSV-surviving Atlantic salmon + sentinel herring tanks on 5, 8, 11, and $12 \mathrm{~d}$ into cohabitation. The tanks were monitored daily for up to $42 \mathrm{~d}$, during which mortalities were collected and immediately stored at $-80^{\circ} \mathrm{C}$ (Table 2). To confirm VHSV infection among mortalities, anterior kidney was analysed via virus isolation assay on EPC cell culture.

\subsection{VHSV detection in tissue samples via RT-qPCR}

Total RNA was extracted from fish tissues with TRIzol Reagent (Ambion) following the manufacturer's protocol. Briefly, tissue samples up to $100 \mathrm{mg}$ were homogenized with a $5 \mathrm{~mm}$ stainless steel bead at $25 \mathrm{~Hz}$ for $2 \mathrm{~min}$ using a TissueLyser (Qiagen). Extracted RNA was suspended in $50 \mu$ l RNase- and DNase-free Ultrapure Distilled Water (Invitrogen), incubated at $55^{\circ} \mathrm{C}$ for $10 \mathrm{~min}$, immediately chilled on ice, and stored at $-80^{\circ} \mathrm{C}$ if it was not analyzed on the day of extraction. The concentration and purity of the RNA was determined with an ND-1000 Spectrophotometer (NanoDrop Technologies) with $1.5 \mu \mathrm{g}$ template being used in a VHSV specific RT-qPCR (Garver 
et al. 2011). Duplicate reactions were run in a Stratagene Mx3000P qPCR System, and data were analyzed using MxPro QPCR Software (Agilent Technologies) with results reported as the ROX normalized average $C_{\mathrm{t}}$ value of duplicate reactions. A sample was considered positive for VHSV when a $C_{\mathrm{t}}$ value of $\leq 40$ was measured in duplicate reactions. Positive and negative quality controls were included for RNA extraction and at each step of the RT-qPCR assay.

\subsection{Statistical analysis}

Herring mortality data from the cohabitation study was plotted using Kaplan-Meier survival analysis with Log-Rank testing. Herring survival curves were compared using the Holm-Sidak method of multiple comparisons (SigmaPlot 13.0).

\section{RESULTS}

Sockeye salmon Oncorhynchus nerka demonstrated nominal susceptibility to VHSV infection after exposure by IP injection. Of the 195 sockeye salmon that were not sub-sampled during the experiment, 1 mortality (0.5\%) occurred (Day 17 ) throughout the 20 d experimental period. Hemorrhaging was observed on the ventral surface of the dead fish, and VHSV was isolated from the anterior kidney at a titer of $9.4 \times 10^{7} \mathrm{PFU} \mathrm{g}^{-1}$. RT-qPCR of anterior kidney, gill, and brain tissue confirmed the identity as VHSV. VHSV was detected by RT-qPCR in only 2 of 30 sockeye salmon sub-sampled throughout the study, including 0 of 10 on Day 7, 1 of 10 on Day 14, and 1 of 10 on Day 20 post exposure; average $C_{\mathrm{t}}$ values ranged from 19.42 (anterior kidney) to 29.89 (brain). In contrast, mortality was $58 \%$ among VHSV-exposed Atlantic salmon Salmo salar ( $\mathrm{N}=144)$, and VHSV was isolated from all examined mortalities $(n=10)$ with mean anterior kidney titers ranging from $1.6 \times$ $10^{6} \mathrm{PFU} \mathrm{g}^{-1}$ to $4.4 \times 10^{7} \mathrm{PFU} \mathrm{g}^{-1}$. Mortality did not occur in any of the negative control groups.

Sockeye salmon demonstrated no susceptibility to VHSV infection after waterborne exposure. The actual virus exposure titer determined from tank water samples at the start of challenge was close to the predicted dose, ranging from $2.8 \times 10^{3} \mathrm{PFU} \mathrm{ml}^{-1}$

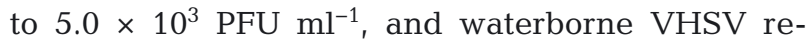
mained detectable in the treatment tanks after $1 \mathrm{~h}$. VHSV was not detected in any water samples from either negative control tank. No mortality occurred among the sockeye salmon or Atlantic salmon that were exposed to waterborne VHSV. Furthermore, VHSV was not detected by RT-qPCR in any of the sockeye salmon sampled on 7, 14, and $20 \mathrm{~d}$ post VHSV exposure $\left(n=10\right.$ fish $\left.\mathrm{d}^{-1}\right)$. No mortalities occurred in the negative control groups.

An active VHSV epizootic in Pacific herring Clupea pallasii was initiated after waterborne exposure to $2.3 \times 10^{2} \mathrm{PFU} \mathrm{ml} \mathrm{ml}^{-1}$ to $3.7 \times 10^{2} \mathrm{PFU} \mathrm{m}{ }^{-1}$. After resumption of supply water to the tanks, waterborne VHSV was undetectable at $3 \mathrm{~d}$ post exposure but was isolated from the tank water $6 \mathrm{~d}$ post exposure and peaked at $10 \mathrm{~d}$ post exposure, with an average of $6.0 \times 10^{2} \mathrm{PFU} \mathrm{ml} \mathrm{m}^{-1}$ in the herring + sockeye tanks. Waterborne VHSV reached similar levels across the herring + salmon cohabitant tanks with the exception of 1 tank of herring + Atlantic salmon $(\mathrm{Ph}+\mathrm{As} 1)$ that had higher levels of virus on Day 10 post exposure (Fig. 1). Survival was significantly lower $(\mathrm{p}<0.05)$ among VHSV-exposed Pacific herring (0 to 27.6\%) than among unexposed controls (53.1 to 78.1\%) for each cohabitation treatment (Atlantic salmon or sockeye salmon); additionally, survival was significantly lower $(\mathrm{p}<0.05)$ among Pacific herring that were cohabitated with Atlantic salmon than those cohabitated with sockeye salmon (Fig. 2). VHSVassociated mortality began in Pacific herring at $5 \mathrm{~d}$ post exposure, and VHSV was recovered on EPC cell culture from $81.5 \%(\mathrm{n}=54)$ of the herring mortalities from the sockeye cohabitation and $86.0 \%(n=43)$ of the herring mortalities from the Atlantic salmon cohabitation. VHSV was not de-

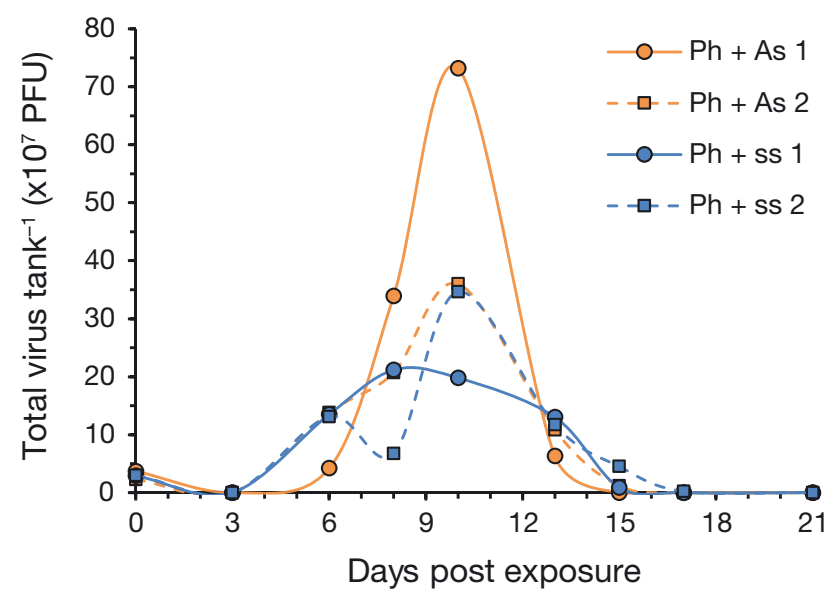

Fig. 1. Levels of shed viral hemorrhagic septicemia virus (VHSV) per tank following waterborne exposure of Pacific herring Clupea pallasii (Ph) to VHSV-IVa. Sockeye salmon Oncorhynchus nerka (ss) or Atlantic salmon Salmo salar (As) were added at $1 \mathrm{~d}$ post exposure. Mean PFU tank ${ }^{-1}$ was calculated from duplicate plaque assay counts 


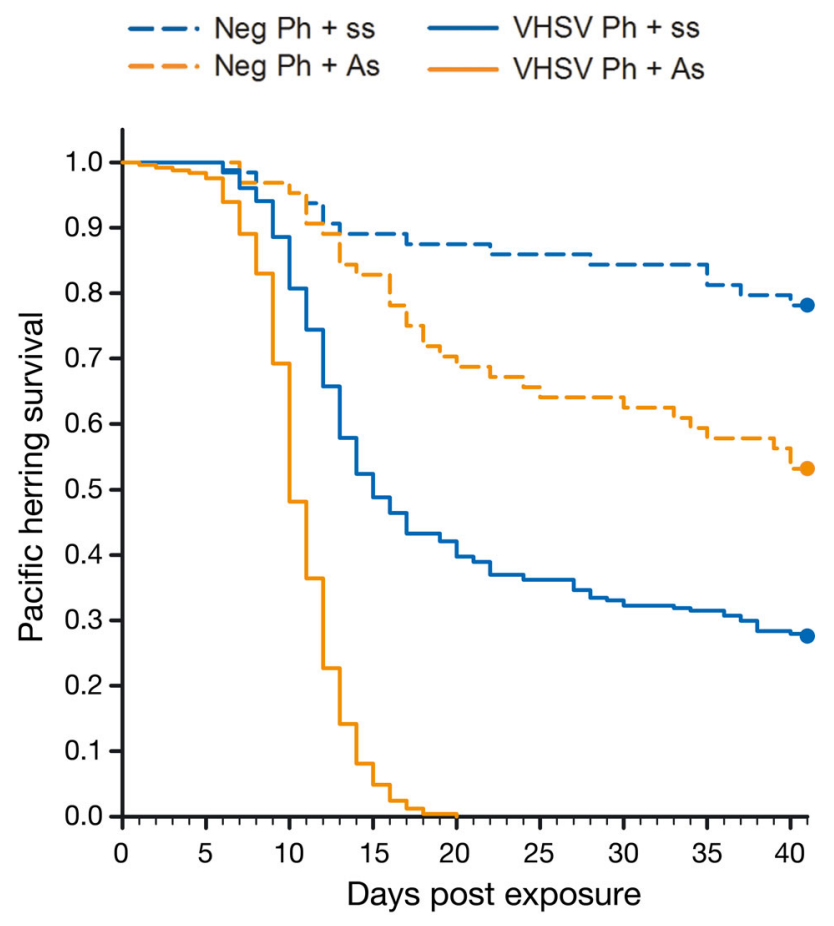

Fig. 2. Survival analysis of Pacific herring (Ph) after waterborne exposure to VHSV-IVa. Sockeye salmon (ss) or Atlantic salmon (As) were added at $1 \mathrm{~d}$ post exposure. The survival curves represent quadruplicate tanks of each VHSV-treated cohabitation, with 1 VHSV-free negative control tank (Neg) for each cohabitation type. A significant difference between survival curves was found in all combinations of survival curve comparisons $(p<0.05)$. The solid circles depict datacensoring due to study completion.

tected in any sub-sampled Pacific herring mortalities from the negative control groups $(n=12$ in the sockeye and $\mathrm{n}=25$ in the Atlantic salmon treatments); similarly, waterborne VHSV was not detected in any of the negative control tanks.

Sockeye salmon demonstrated nominal susceptibility to infection when cohabitated in these active VHSV epizootics affecting Pacific herring. No mortality occurred among the sockeye salmon, whereas mortality occurred among $5.4 \%$ (19 of the 355) of Atlantic salmon. Among the Atlantic salmon mortalities, VHSV was detected from 2 of 19 anterior kidney samples via virus isolation assay on EPC cell culture and RT-qPCR, with average $C_{\mathrm{t}}$ values of 34.84 and 36.73. Interestingly, these 2 VHSVpositive Atlantic salmon mortalities occurred in tank $\mathrm{Ph}+\mathrm{As} 1$, which yielded 4 of the 19 total Atlantic salmon mortalities and displayed relatively higher levels of shed VHSV (Fig. 1). In contrast, tank Ph + As 2 accounted for 2 of the 19 total Atlantic salmon mortalities with no VHSV detection in anterior kidney. Of the regularly sub-sampled fish, VHSV was transiently detected in gill tissue, but not the anterior kidney, from both sockeye and Atlantic salmon on Days 6, 10, and up to 15 for sockeye salmon, with average $C_{\mathrm{t}}$ values ranging from 32.44 to 37.48. Among negative controls, VHSV was not detected in any sockeye salmon or Atlantic salmon, nor was any virus detected in any Atlantic salmon mortalities $(\mathrm{N}=7)$.

There was no evidence that sockeye or Atlantic salmon served as a reservoir for VHSV. Among 10 tanks containing sockeye and Atlantic salmon that survived prior VHSV exposure, no VHSV was detected from sub-samples of either VHSV-exposed or sentinel salmon. In these tanks, mortality occurred among cohabitating sentinel Pacific herring and Atlantic salmon; however, VHSV was not isolateyd from the examined mortalities (Table 3) or water samples, and survival of sentinel herring was similar to that of the respective negative controls. In contrast, VHSV was detected in $100 \%(\mathrm{n}=19)$ of the sub-sampled mortalities from sentinel herring that were cohabitated with herring that survived prior VHSV exposure (Table 3). VHSV was not detected in any sub-sampled mortalities in the negative control treatments, including herring from the sockeye cohabitation $(\mathrm{n}=3)$, herring from the Atlantic salmon cohabitation $(\mathrm{n}=15)$, or a single Atlantic salmon.

Table 3. Mortality of VHSV-exposed survivors and naïve sentinel fish in the VHSV reservoir potential study. A proportion of the mortalities were tested for VHSV by virus isolation assay (na: not applicable; neg: all samples tested negative; pos: all samples tested positive)

\begin{tabular}{|c|c|c|c|c|c|}
\hline \multirow[t]{2}{*}{ Survivors } & \multirow{2}{*}{$\begin{array}{l}\text { Cohabitation } \\
\text { Sentinels }\end{array}$} & \multicolumn{2}{|c|}{$\longrightarrow$ Survivors $\longrightarrow$} & \multicolumn{2}{|c|}{ Sentinels } \\
\hline & & $\%$ Mortality & Dead fish tested & \% Mortality & Dead fish tested \\
\hline Sockeye salmon & Pacific herring & $0.0(0 / 181)$ & na & $12.4(21 / 169)$ & $21 / 21$ (neg) \\
\hline Atlantic salmon & Pacific herring & $3.9(7 / 178)$ & 7/7 (neg) & $84.6(143 / 169)$ & $50 / 143$ (neg) \\
\hline Sockeye salmon & Atlantic salmon & $0.0(0 / 120)$ & na & $0.8(1 / 119)$ & $1 / 1$ (neg) \\
\hline Atlantic salmon & Sockeye salmon & $4.2(5 / 118)$ & 5/5 (neg) & $0.0(0 / 119)$ & na \\
\hline Pacific herring & Pacific herring & $3.3(2 / 61)$ & $2 / 2$ (pos) & $45.5(30 / 66)$ & 19/30 (pos) \\
\hline
\end{tabular}




\section{DISCUSSION}

Knowledge of the susceptible host species range of a specific pathogen is instrumental for containing its spread and preventing its introduction into pathogenfree areas. Based on criteria established by the World Organisation for Animal Health (OIE), a suspect host species is considered susceptible to infection when a definitive diagnosis of the pathogen occurs from natural transmission events or under experimental conditions mimicking natural pathways of infection (OIE 2018). Herein we provide evidence that saltwaterphase sockeye salmon Oncorhynchus nerka fail to fulfill the criteria of a VHSV-susceptible species as no virus was detected or isolated from this species after exposure to the virus under conditions reflective of a natural transmission route. These results extend findings of previous studies that demonstrated sockeye salmon to be refractory to VHSV when exposed in freshwater (Follett et al. 1997, Traxler et al. 1999) and indicate that sockeye salmon likely maintain resistance to VHSV infection through both fresh and seawater phases of their life cycle.

In the Northeast Pacific Ocean, VHSV-IVa is the sole genotype present where it occurs across a broad range of marine fishes (Hedrick et al. 2003, Garver et al. 2013). Pacific herring Clupea pallasii is one species that has proven to be a natural reservoir of VHSV whereby under some circumstances, these covert infections cascade to epizootics of VHS disease (Hershberger et al. 2016). During such mortality events, VHSdiseased Pacific herring shed enormous amounts of virus, resulting in the rapid amplification of exogenous virus that can be a source to sympatric fishes (Hershberger et al. 2010). Such viral transmission events are evident by concurrent isolations of VHSV from Pacific herring and Atlantic salmon Salmo salar after aggregations of VHS-diseased Pacific herring were found in and around open net-pen salmon farms of British Columbia (Garver et al. 2013). Given their abundance and contribution as a dominant member of the forage fish assemblage in the North Pacific Ocean, Pacific herring undoubtedly interact with Pacific salmon and have been hypothesized as the source of the uncommon VHSV detections made in Chinook O. tshawytscha and coho salmon O. kisutch (Meyers \& Winton 1995, Amos et al. 1998). Additionally, purse seine and trawl surveys conducted throughout the Salish Sea have documented the co-occurrence and natural interaction of Pacific herring with Pacific salmon species, including sockeye salmon (Grant et al. 2018).

It was not surprising that exposure of Pacific herring, a highly susceptible species, to waterborne VHSV resulted in an epizootic accompanied with copious viral shedding. Levels of waterborne virus shed during the epizootic were relatively equivalent across tanks where the Atlantic and sockeye salmon cohabitants remained free of VHSV. However, in the 1 tank where the sentinel Atlantic salmon became VHSV infected (tank $\mathrm{Ph}+\mathrm{As}$ 1, Fig. 1), a higher peak level of waterborne virus was observed, suggesting that the infected Atlantic salmon likely shed virus thereby enhancing the level of waterborne virus. Meanwhile, in the tanks where the salmonid cohabitants remained free of VHSV, the levels of shed virus were solely a reflection of the herring epizootic.

The levels of waterborne VHSV generated because of donor herring succumbing to VHS disease reached levels mirroring those measured in natural marine environs. In the vicinity of a high-density Pacific herring spawn-on-kelp fishery, waterborne titers of VHSV were measured at $7 \times 10^{2} \mathrm{PFU} \mathrm{ml}^{-1}$ (Hershberger et al. 1999), similar to the peak titer of $6.0 \times 10^{2} \mathrm{PFU} \mathrm{ml}^{-1}$ measured in the Pacific herring + sockeye cohabitation tanks. Despite sockeye salmon receiving daily exposure to waterborne virus naturally shed from infected herring, systemic VHSV infections remained absent. However, these cohabitation conditions were sufficient to transmit VHSV to Atlantic salmon, resulting in VHSV infections of the kidney and corroborating the susceptibility of this species (Lovy et al. 2013). It is worthwhile noting however that despite the absence of systemic VHSV infections in sockeye salmon exposed to waterborne virus, RT-qPCR detections of VHSV were occasionally made from gill samples. Given that these detections were at similar quantities to tank water samples (K. Garver unpubl. data) and that corresponding kidney tissues remained negative for VHSV, these occurrences were likely a reflection of the presence of virus in the water or superficial association on the surface of the gills rather than an indication of true infection.

Under the exposure conditions employed in these studies, neither sockeye salmon nor Atlantic salmon survivors of prior VHSV exposure were successful reservoirs of the virus. For VHSV-exposed sockeye salmon, the inability to transmit virus to highly susceptible cohabitating Pacific herring is not surprising given that waterborne exposures of sockeye salmon to VHSV failed to initiate an infection. In regard to the reservoir potential of Atlantic salmon, it is unknown why our study failed to demonstrate them as a reservoir species, as transmission of VHSV from previously exposed Atlantic salmon to cohabiting naïve Pacific herring was previously demonstrated (Lovy et al. 2013). Although differences in experimental designs 
preclude direct comparisons between studies, a higher infection rate of Atlantic salmon as reported by Lovy et al. (2013) in comparison to those observed in our study, suggest that the severity of the primary VHSV exposure may be a predicting factor in establishing a reservoir state. It is worth noting that in our study, Pacific herring survivors of prior VHSV exposure successfully transmitted virus to naïve cohabiting herring, revealing their greater propensity as a source of VHSV than either Atlantic salmon or sockeye salmon.

The refractory nature of sockeye salmon to VHSV infection as observed in our controlled laboratory exposure studies is consistent with the absence of a confirmed detection or isolation of VHSV in a natural sockeye salmon population. A presumptive positive RT-PCR detection of VHSV has been reported in juvenile sockeye salmon collected in the marine waters of British Columbia (Marty et al. 2006), whereas surveillance efforts collectively examining $>2400$ marine-phase sockeye salmon demonstrated freedom of VHSV infection (Kent et al. 1998, Nekouei et al. 2018). The lack of susceptibility of sockeye salmon to VHSV-IVa infections by immersion and cohabitation, together with absence of infection in wild stocks, suggests that waterborne exposure of sockeye salmon will not result in infection.

The mechanism(s) accounting for resistance to VHSV infection are unknown; however, our results indicate that when the virus exposure route circumvented the exterior barrier of the fish via IP injection, virus infection was enhanced. This enhancement of infections, albeit minimal for sockeye salmon (detected in the single mortality and 2 of 30 sub-sampled fish), indicates the importance of the exterior surface of the fish in maintaining the fish's resistance to VHSV infection. Interestingly, in line with the refractory nature of sockeye salmon as demonstrated in our study, Pacific salmon species in general appear less susceptible to infection with VHSV-IVa, suggesting the potential for shared resistance mechanism(s) among the Pacific salmonids. On the west coast of North America, a limited number of natural detections of VHSV-IVa infections have been reported for Chinook and coho salmon, yet these infections were not associated with VHS disease (Amos et al. 1998). Furthermore, laboratory studies investigating VHSV susceptibility of Pacific salmon have corroborated their limited susceptibility to VHSV-IVa (Winton et al. 1991, Follett et al. 1997, Amos et al. 1998, Traxler et al. 1999, Emmenegger et al. 2013). Nevertheless, the question of whether a fish becomes infected and diseased is undoubtedly contingent upon not only the host species but also the viral strain and environ- mental conditions under which the virus exposure occurs. This is best exemplified by the fact that marine North American VHSV (genotype IVa) is relatively less virulent to rainbow trout Oncorhynchus mykiss than freshwater European VHSV (genotype I) (Winton et al. 1991, Follett et al. 1997, Snow et al. 2004, Skall et al. 2005, Emmenegger et al. 2013). Consequently, additional studies are required to better understand not only mechanisms of host resistance but also the molecular determinants of VHSV virulence.

Acknowledgements. We thank Haley Matkin, Laura Hawley, and Kimberly Taylor for their advice and technical assistance with sample collection and processing. We also thank Holly Hicklin and Elizabeth Shemming for assisting with fish care and Amy Long for assistance with statistical analyses.

\section{LITERATURE CITED}

Amos K, Thomas J, Hopper K (1998) A case history of adaptive management strategies for viral hemorrhagic septicemia virus (VHSV) in Washington State. J Aquat Anim Health 10:152-159

Batts WN, Traxler GS, Winton JR (1991) Factors affecting the efficiency of plating for selected fish rhabdoviruses. In: Fryer JL (ed) Proc 2nd Int Symp Viruses of Lower Vertebrates, July 29-31, Oregon University, Corvallis, OR, p $17-24$

Burgner RL (1991) Life history of sockeye salmon (Oncorhynchus nerka). In: Groot C, Margolis L (eds) Pacific salmon life histories. UBC Press, Vancouver, p 1-117

Cohen BI (2012) Cohen Commission of Inquiry into the decline of sockeye salmon in the Fraser River - final report. Canada Privy Council, Ottawa, http://publications.gc.ca/pub?id= $9.652609 \& \mathrm{sl}=0$ (accessed 22 February 2019)

EFSA (European Food Safety Authority) (2008) Scientific Opinion of the Panel on AHAW on a request from the European Commission on aquatic animal species susceptible to diseases listed in the Council Directive 2006/88/ EC. EFSA J 808:1-144

Emmenegger EJ, Moon CH, Hershberger PK, Kurath G (2013) Virulence of viral hemorrhagic septicemia virus (VHSV) genotypes Ia, IVa, IVb, and IVc in five fish species. Dis Aquat Org 107:99-111

Follett JE, Meyers TR, Burton TO, Geesin JL (1997) Comparative susceptibilities of salmonid species in Alaska to infectious hematopoietic necrosis virus (IHNV) and North American viral hemorrhagic septicemia virus (VHSV). J Aquat Anim Health 9:34-40

Garver KA, Hawley LM, McClure CA, Schroeder T and others (2011) Development and validation of a reverse transcription quantitative PCR for universal detection of viral hemorrhagic septicemia virus. Dis Aquat Org 95:97-112

Garver KA, Traxler GS, Hawley LM, Richard J, Ross JP, Lovy J (2013) Molecular epidemiology of viral haemorrhagic septicaemia virus (VHSV) in British Columbia, Canada, reveals transmission from wild to farmed fish. Dis Aquat Org 104:93-104

Grant SCH, Holt C, Wade J, Mimeault C, Burgetz IJ, Johnson S, Trudel M (2018) Summary of Fraser River sockeye salmon (Oncorhynchus nerka) ecology to inform patho- 
gen transfer risk assessments in the Discovery Islands, BC. DFO Can Sci Advis Secr Res Doc 2017/074

Hedrick RP, Batts WN, Yun S, Traxler GS, Kaufman J, Winton JR (2003) Host and geographic range extensions of the North American strain of viral hemorrhagic septicemia virus. Dis Aquat Org 55:211-220

Hershberger PK, Kocan RM, Elder NE, Meyers TR, Winton JR (1999) Epizootiology of viral hemorrhagic septicemia virus in Pacific herring from the spawn-on-kelp fishery in Prince William Sound, Alaska, USA. Dis Aquat Org 37: 23-31

Hershberger P, Gregg J, Grady C, Collins R, Winton J (2010) Kinetics of viral shedding provide insights into the epidemiology of viral hemorrhagic septicemia in Pacific herring. Mar Ecol Prog Ser 400:187-193

Hershberger PK, Garver KA, Winton JR (2016) Principles underlying the epizootiology of viral hemorrhagic septicemia in Pacific herring and other fishes throughout the North Pacific Ocean. Can J Fish Aquat Sci 73:853-859

Kent ML, Traxler GS, Kieser D, Richard J and others (1998) Survey of salmonid pathogens in ocean-caught fishes in British Columbia, Canada. J Aquat Anim Health 10: 211-219

Kocan RM, Hershberger PK, Elder NE, Winton JR (2001) Epidemiology of viral hemorrhagic septicemia among juvenile Pacific herring and Pacific sand lances in Puget Sound, Washington. J Aquat Anim Health 13:77-85

Lovy J, Piesik P, Hershberger PK, Garver KA (2013) Experimental infection studies demonstrating Atlantic salmon as a host and reservoir of viral hemorrhagic septicemia virus type IVa with insights into pathology and host immunity. Vet Microbiol 166:91-101

Marty GD, Karreman GA, Jones S (2006) Prevalence and seasonality of new pathogens in juvenile salmonids from inner coastal British Columbia, Canada. In: 47th Western Fish Disease Workshop, June 26-28, Victoria,

Editorial responsibility: Lori Gustafson,

Fort Collins, Colorado, USA
British Columbia

* Meyers TR, Winton JR (1995) Viral hemorrhagic septicemia virus in North America. Annu Rev Fish Dis 5:3-24

Meyers TR, Short S, Lipson K (1999) Isolation of the North American strain of viral hemorrhagic septicemia virus (VHSV) associated with epizootic mortality in two new host species of Alaskan marine fish. Dis Aquat Org 38: 81-86

Nekouei O, Vanderstichel R, Ming T, Kaukinen KH and others (2018) Detection and assessment of the distribution of infectious agents in juvenile Fraser River sockeye salmon, Canada, in 2012 and 2013. Front Microbiol 9:3221

OIE (World Organisation for Animal Health) (2018) Aquatic animal health code. www.oie.int/standard-setting/aquaticcode/access-online/ (accessed $10 \mathrm{Jul}$ 2019)

OIE (World Organisation for Animal Health) (2019) Manual of diagnostic tests for aquatic animals. www.oie.int/ standard-setting/aquatic-manual/access-online/ (accessed 10 Jul 2019)

Skall HF, Olesen NJ, Mellergaard S (2005) Viral haemorrhagic septicaemia virus in marine fish and its implications for fish farming - a review. J Fish Dis 28: 509-529

Snow M, Bain N, Black J, Taupin V and others (2004) Genetic population structure of marine viral haemorrhagic septicaemia virus (VHSV). Dis Aquat Org 61:11-21

Traxler GS, Kieser D, Richard J (1999) Mass mortality of pilchard and herring associated with viral hemorrhagic septicemia virus in British Columbia, Canada. Fish Health Sect Am Fish Soc Newsl 27:3-4

Winton JR, Batts WN, Deering RE, Brunson R, Hopper K, Nishizawa T, Stehr C (1991) Characteristics of the first North American isolates of viral hemorrhagic septicemia virus. In: Fryer JL (ed) Proc 2nd Int Symp Viruses of Lower Vertebrates, July 29-31, Oregon University, Corvallis, OR, p 43-50

Submitted: May 15, 2019; Accepted: July 17, 2019

Proofs received from author(s): August 30, 2019 